\title{
$\mathrm{H}_{2}$ and $\mathrm{CH}_{4}$ Sorption on Cu-BTC Metal Organic Frameworks at Pressures up to $15 \mathrm{MPa}$ and Temperatures between 273 and $318 \mathrm{~K}$
}

\section{Yves Gensterblum}

Institute of Geology and Geochemistry of Petroleum and Coal, RWTH Aachen University, Lochnerstr Aachen, Germany. Email: gensterblum@lek.rwth-aachen.de

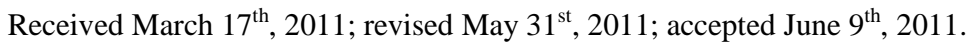

\begin{abstract}
Sorption isotherms of methane and hydrogen on $\mathrm{Cu}_{3}(B T C)_{2}$ have been measured in the temperature range from 273 to $318 \mathrm{~K}$ and at pressures up to $15 \mathrm{MPa}$. $\mathrm{H}_{2}$ excess sorption capacities of the $\mathrm{Cu}_{3}(\mathrm{BTC})_{2}$ amounted to $3.9 \mathrm{mg} / \mathrm{g}$ at $14 \mathrm{MPa}$. Promising maximum $\mathrm{CH}_{4}$ excess sorption capacities on the same sample were reached at approximately $5 \mathrm{MPa}$. They amounted to 101, 100, 92 and $80 \mathrm{mg} / \mathrm{g}$ at 273, 278, 293 and $318 \mathrm{~K}$, respectively. The sorbed phase density was essentially the same for all temperatures and amounted to $\sim 600 \mathrm{~kg} / \mathrm{m}^{3}$. Structural changes of the $\mathrm{Cu}_{3}(B T C)_{2}$ samples after thermal activation and treatment with high pressure $\mathrm{H}_{2}$ and $\mathrm{CH}_{4}$ were tested. It was found that the initial micropore structure has virtually disappeared as evidenced by a decrease of the Langmuir specific surface area by a factor $\sim 3$ and $\mathrm{CO}_{2}$ micropore volume by a factor of $\sim 4$ for $\mathrm{H}_{2}$ and $\sim 3$ for $\mathrm{CH}_{4}$. This is in line with an increase in the average pore diameter from initially 9.2 to 15.7 for $\mathrm{H}_{2}$ and 12.8 for $\mathrm{CH}_{4}$.
\end{abstract}

Keywords: Metal Organic Framework (MOF), Sorption, Methane, Hydrogen, Pore Structure

\section{Introduction}

The concept of reticular design in the synthesis of metal organic frameworks (MOF) permits custom-tailoring of regular pore structures on the nanometer scale [1]. This approach opens new perspectives for the development of gas and energy storage systems [2]. So far, the gas sorption capacity of metal-organic frameworks (MOF) of various chemical and structural compositions has mainly been determined at low pressures $(<0.1 \mathrm{MPa})$ and temperatures $(77$ to $87 \mathrm{~K}$ ). Only a few studies $[3,4]$ reported $\mathrm{H}_{2}$ and $\mathrm{CO}_{2}$ measurements at ambient temperatures (ideal operating temperature).

Several authors reported the internal structure of different MOFs [5,6]; however, significant amounts of side products were detected using the synthesis described by Chui et al. (1999)[5]. One major problem concerning the storage of gases on these materials at high pressures ( $>1$ $\mathrm{MPa}$ ) and temperatures (especially at the activation temperature of $458 \mathrm{~K}$ ) is their structural instability and hence, a decrease in specific surface area associated with struc- tural rearrangements for $\mathrm{Cu}-(\mathrm{BTC})$ [6].

In this study the sorption capacities of $\mathrm{CH}_{4}$ and $\mathrm{H}_{2}$ on
$\mathrm{Cu}_{3}(\mathrm{BTC})_{2}$ (Copper benzene-1,3,5-tricarboxylate, $\mathrm{C}_{18} \mathrm{H}_{6}$ $\mathrm{Cu}_{3} \mathrm{O}_{12}$ ) have been investigated at temperatures between 273 and $318 \mathrm{~K}$ and pressures up to $15 \mathrm{MPa}$. Specific surface areas (SSA) and pore size distributions (PSD) have been determined on untreated samples before and after high-pressure sorption experiments in order to detect any structural changes of the sample due to the interaction with the gases. A similar approach has been used by [7], who reported changes in SSA and PSD on MOF-5 during hydrogen sorption.

Two slightly different MOFs both consist of the same organic ligands but with different basic metals $\mathrm{Al}^{3+}$ and $\mathrm{Cr}^{3+}$ ) [8]. At 77K the $\mathrm{Al}^{3+}-\mathrm{MOF}$ shows higher sorption capacities than the corresponding $\mathrm{Cr}^{3+}$ sample. However, both samples nearly show the same specific surface area of $\sim 1000 \mathrm{~m}^{2} / \mathrm{g}$ (Figure 1). This finding confirms the importance of micropore volume and the electrostatical potential of the different metals.

Data provided in Figure 1 reflects the general correlation between SSA (determined by low pressure $\mathrm{N}_{2}$-isotherms at $77 \mathrm{~K}$ ) and $\mathrm{H}_{2}$ sorption capacity at $77 \mathrm{~K}$. It is known that this trend is ambiguous for isotherms recorded at higher temperatures [9]. One suggestion is that 


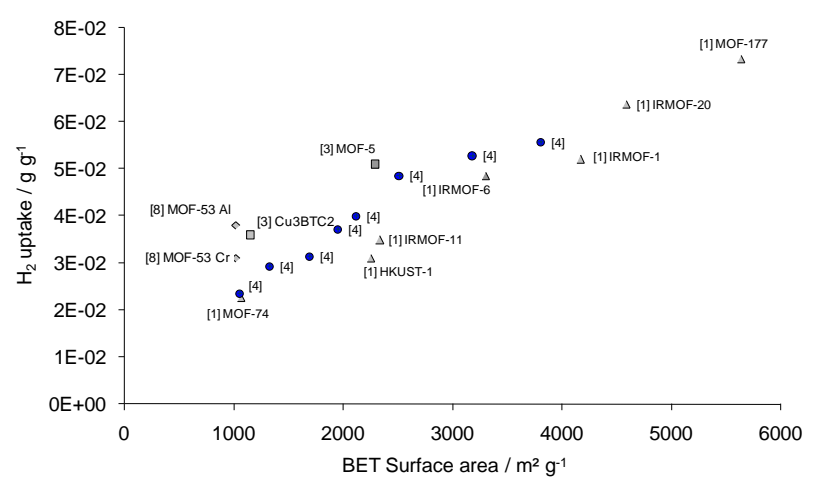

Figure 1. Comparison of high-pressure ( $\sim \mathrm{MPa}) \mathrm{H}_{2}$ sorption capacities at $77 \mathrm{~K}$ vs. $\mathrm{N}_{2}$-BET surface area for different MOFs and carbon materials.

a better correlation can be obtained by separating the hydrogen adsorbed in the micropores from that on the surface of the mesopores. Furthermore, Nijkamp et al. (2001) concluded that a higher storage capacity could be achieved with adsorbents containing a large micropore volume with suitable diameter [9].

In a study on hydrogen storage in chemically activated carbons and carbon nanomaterials, Beneyto (2007) [10] proposes that at $77 \mathrm{~K}$ the $\mathrm{H}_{2}$ adsorption capacity depends on the SSA and the total micropore volume of the activated carbon. At $298 \mathrm{~K}$ it depends on both the micropore volume and the micropore size distribution. To date, very few high pressure/temperature isotherms and corresponding micropore volumes have been determined on MOFs.

In comparison to hydrogen, it was shown for methane in different studies that $\mathrm{Cu}_{3}(\mathrm{BTC})_{2}$ has a high $\mathrm{CH}_{4}$ storage capacity at room temperature [11,12] (295 to $298 \mathrm{~K}$, Wang et al. 2002; Lin et al. 2006). Sorption values on Cu-BTC for $\mathrm{CH}_{4}$ of up to $72 \mathrm{mg} / \mathrm{g}$ (at $295 \mathrm{~K}$ and 0.1 $\mathrm{MPa}$ ) with nearly linear sorption isotherms up to 0.1 MPa [11]. Maximum $\mathrm{CH}_{4}$ sorption capacities of 31.4 $\mathrm{mg} / \mathrm{g}$ at $0.9 \mathrm{MPa}$ and $298 \mathrm{~K}$ on $\mathrm{Zn}-\mathrm{MOF}$ and a hysteresis between the sorption and desorption curves [12]. Senkovska and Kaskel (2007) [13] reported high pressure $\mathrm{CH}_{4}$ adsorption on $\mathrm{Cu}_{3}(\mathrm{BTC})_{2}, \mathrm{Zn}_{2}$ (bdc) $)_{2} \mathrm{dabco}, \mathrm{Cr}_{3} \mathrm{~F}\left(\mathrm{H}_{2} \mathrm{O}\right)_{2}$, $\mathrm{O}(\mathrm{bdc})_{3}$. Among the three materials, $\mathrm{Cu}_{3}(\mathrm{BTC})_{2}$ shows the highest excess adsorption at $303 \mathrm{~K}(15.7 \mathrm{mg} / \mathrm{g})$.

\section{Experimental}

\subsection{High-Pressure Sorption Experiments}

High pressure single-gas adsorption experiments have been performed using a manometric experimental set-up (Figure 2) consisting of a stainless-steel measuring cell (MC) and a calibrated reference volume (RC) connected with a set of actuator-driven valves and a high-precision

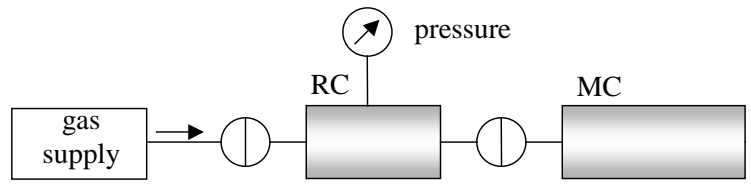

Figure 2. Schematic diagram of sorption apparatus used for high pressure/high temperature $\mathrm{H} 2$ and $\mathrm{CH} 4$ sorption experiments on Cu-BTC MOFs. (RC = calibrated reference volume ; $\mathrm{MC}=$ measuring cell).

pressure transducer (max. pressure $25 \mathrm{MPa}$, with a precision of $0.05 \%$ of the full scale value). The entire device is placed in a temperature-controlled oven (variations in temperature $<0.1 \mathrm{~K}$ ). Calculation of the excess sorption was performed based on equations of state by Setzman and Wagner (1991) [14] and McCarty et al. (1981) [15] for methane and hydrogen, respectively. Quality control is ensured by participation in laboratory comparison studies (e.g. Gensterblum et al. 2009 [16], 2010 [17] and Goodman et al. 2004 [18]). For further details on the experimental approach, please refer to e.g. Busch et al. (2004) [19].

As pointed out by Férey (2003) [8] for the MIL-53 and Schlichte et al. (2004) [6] for the MOFs - which were also investigated in this study - the activation of the metal-organic framework compounds is an important issue affecting the quality and reproducibility of sorption capacity measurements. The activation procedure was carried out in three stages: $12 \mathrm{~h}$ at $105^{\circ} \mathrm{C}, 12 \mathrm{~h}$ at $155^{\circ} \mathrm{C}$, and finally $18 \mathrm{~h}$ at $185^{\circ} \mathrm{C}$. This activation procedure led to well-reproducible starting conditions for the isotherm measurements.

Error bars shown in the diagrams and error margins listed in the Table 2 were determined based on the Gauss error propagation method considering the individual errors of the individual experimental parameters.

\subsection{Characterisation of Pore Structure and Surface Area}

A Quantachrome Autosorb 1 instrument was used to characterise the pore structure and surface properties of the samples. The latter has been performed using the equation proposed by Brunauer, Emmet and Teller (1938, BET) [20]. The pore size distribution for 1.2 up to $40 \mathrm{~nm}$ pore diameters were derived by $\mathrm{N}_{2}$-isotherms measured at $77 \mathrm{~K}$. Pore size distributions (PSD) were analysed [21,22] and the nonlinear density functional theory (NLDFT, Thommes et al. 2006) [23]. The submicro- and micropores, in the range of 0.3 to $1.5 \mathrm{~nm}$, were charac- terised by $\mathrm{CO}_{2}$ isotherms measured at $273 \mathrm{~K}$. These iso- therms were also evaluated according to the Dubinin and NLDFT methods. For the NLDFT evaluation, slit and/or cylindrical pores were assumed which 
represents a com- promise between availability of mathematical PSD-al- gorithms with spherical pore structure and real pore structures.

\section{Results and Discussion}

\subsection{Sorption Capacities}

\subsubsection{Hydrogen}

Figure 3 shows the $\mathrm{H}_{2}$ excess sorption isotherms for $\mathrm{Cu}_{3}(\mathrm{BTC})_{2}$ (HKUST-1), measured at $318 \mathrm{~K}$, in compareson with similar literature data reported for $\mathrm{Cu}_{3}(\mathrm{BTC})_{2}$ at 298 K [7]. The higher sorption capacities reported by Panella et al. (2005) [7] can be explained by lower experimental temperatures used. The rather linear trend (Freundlich or Langmuir-Freundlich type) of the sorption isotherms is comparable to other isotherm data (see Figure 1), but it is not a classical Langmuir type as would be expected for porous materials.

Structural changes (pore structure, specific surface area) of the $\mathrm{Cu}_{3}(\mathrm{BTC})_{2}$ after $\mathrm{H}_{2}$ sorption have been determined; the results are provided in Table 1. It is obvious that specific surface areas (SSA) decrease by a factor of 3-4, $\mathrm{N}_{2}$ pore volumes by a factor of $2-3$, and $\mathrm{CO}_{2} \mathrm{mi}-$ cropore volumes by a factor of $4-5$, while an increase in the Dubinin-Astakhov (DA) average pore diameter from 9.2 to $15.7 \AA\left(10^{-10} \mathrm{~m}\right)$ can be observed.

Compared to the $\mathrm{N}_{2}$ micropore volumes for $\mathrm{Cu}_{3}(\mathrm{BTC})_{2}$ determined in this study $0.63 \mathrm{~cm}^{3} \mathrm{~g}^{-1}$ (Table 1), several authors obtained values between 0.41 and $0.76 \mathrm{~cm}^{3} \mathrm{~g}^{-1}$ on virgin samples $[13,24,25]$. Other studies report BET surface areas for this material of $1781 \mathrm{~m}^{2} / \mathrm{g}$ (single-point BET) [26], $1154 \mathrm{~m}^{2} / \mathrm{g}$ [7] and $1239 \mathrm{~m}^{2} / \mathrm{g}$ [11] which is similar to the BET surface area of $1246 \mathrm{~m}^{2} / \mathrm{g}$ ascertained in this study (all measured with $\mathrm{N}_{2}$ at $77 \mathrm{~K}$ ).

\subsubsection{Methane}

Methane sorption isotherms on $\mathrm{Cu}_{3}(\mathrm{BTC})_{2}$ have been measured at temperatures between 273 and $318 \mathrm{~K}$ and pressures up to $15 \mathrm{MPa}$ and are provided in Figure 4. Maximum excess sorption values obtained in these measurements are listed in Table 2. They show a generally decreasing trend with temperature from 101 to 79 mg $\mathrm{CH}_{4} / \mathrm{g}$ MOF. After passing a maximum value, the excess sorption isotherms in Figure $\mathbf{4}$ decrease slightly until the final pressure value is reached. This decline above 6 MPa can be attributed to a volumetric effect (non-negligible volume of the sorbed phase) that needs to be considered when calculating absolute sorption capacities. Among others, Humayun and Tomasko (2000) [27] proposed a method to determine the sorbed phase density, which has been applied in this study. This procedure resulted in nearly identical values of 597 to $601 \mathrm{~kg} / \mathrm{m}^{3}$ for

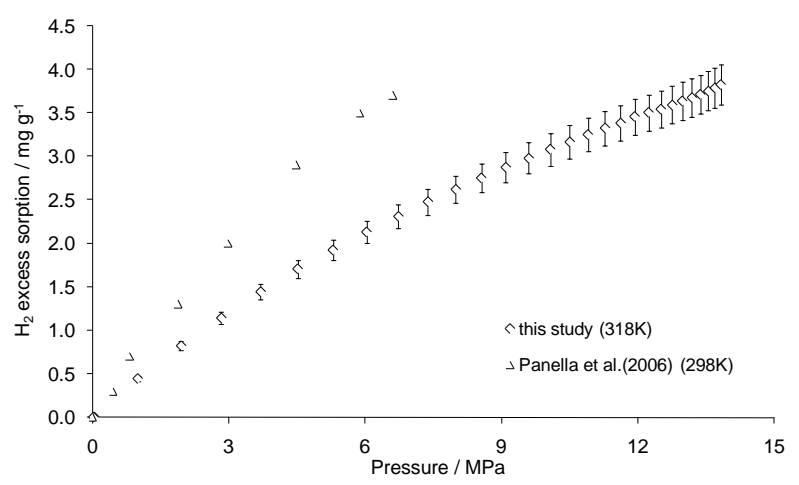

Figure 3. $\mathrm{H}_{2}$ excess sorption capacity measured at $318 \mathrm{~K}$ on $\mathrm{Cu}_{3}$ (BTC) $)_{2}$. For comparison the $\mathrm{H}_{2}$ excess sorption data at $298 \mathrm{~K}$ on $\mathrm{Cu}_{3}(\mathrm{BTC})_{2}$ reported by Panella et al. ${ }^{7}$ has been included.

Table 1. Structural changes of $\mathrm{Cu}_{3}(\mathrm{BTC})_{2}$ after high-pressure $\mathrm{H}_{2}$ sorption experiment at $318 \mathrm{~K}$. DR = Dubinin Radushkewic; NLDFT = non-local density functional theory.

\begin{tabular}{|c|c|c|c|c|c|c|}
\hline $\mathrm{Cu}_{3}(\mathrm{BTC})_{2}$ & method & $\begin{array}{l}\mathrm{N}_{2} \text { surface area } \\
\left(\mathrm{m}^{2} / \mathrm{g}\right)\end{array}$ & $\begin{array}{c}\mathrm{CO}_{2} \text { micropore surface } \\
\text { area }\left(\mathrm{m}^{2} / \mathrm{g}\right)\end{array}$ & $\begin{array}{l}\mathrm{N}_{2} \text { pore volume } \\
\left(\mathrm{cm}^{3} / \mathrm{g}\right)\end{array}$ & $\begin{array}{l}\mathrm{CO}_{2} \text { micropore } \\
\text { volume }\left(\mathrm{cm}^{3} / \mathrm{g}\right)\end{array}$ & $\begin{array}{c}\text { DA pore } \\
\text { diameter }(\AA)\end{array}$ \\
\hline before $\mathrm{H}_{2}$ sorption test & $\begin{array}{c}\text { DR } \\
\text { NLDFT }\end{array}$ & $\begin{array}{l}1731 \\
1994\end{array}$ & $\begin{array}{l}2708 \\
2340\end{array}$ & $\begin{array}{l}0.63 \\
0.64\end{array}$ & $\begin{array}{l}0.94 \\
0.89\end{array}$ & 9.2 \\
\hline after $\mathrm{H}_{2}$ sorption test & $\begin{array}{c}\text { DR } \\
\text { NLDFT }\end{array}$ & $\begin{array}{l}651 \\
576\end{array}$ & $\begin{array}{l}752 \\
641\end{array}$ & $\begin{array}{l}0.23 \\
0.33\end{array}$ & $\begin{array}{l}0.26 \\
0.20\end{array}$ & 15.7 \\
\hline
\end{tabular}

Table 2. $\mathrm{CH}_{4}$ Sorption parameters of $\mathrm{Cu}_{3}(\mathrm{BTC})_{2}$ at 273 to $318 \mathrm{~K}$ considering helium densities.

\begin{tabular}{cccc}
\hline $\mathrm{T}(\mathrm{K})$ & max. excess $\mathrm{CH}_{4}$ sorption capacity $(\mathrm{mg} / \mathrm{g})$ & absolute $\mathrm{CH}_{4}$ sorption capacity $(\mathrm{mg} / \mathrm{g})$ & $\mathrm{CH}_{4}$ sorbed phase density $\left(\mathrm{kg} / \mathrm{m}^{3}\right)$ \\
\hline 273 & $101 \pm 7$ & $113 \pm 3$ & $599 \pm 10$ \\
278 & $100 \pm 7$ & $112 \pm 3$ & $601 \pm 8$ \\
293 & $92 \pm 2$ & $103 \pm 2$ & $597 \pm 5$ \\
318 & $79 \pm 2$ & $90 \pm 3$ & n.d. \\
\hline
\end{tabular}




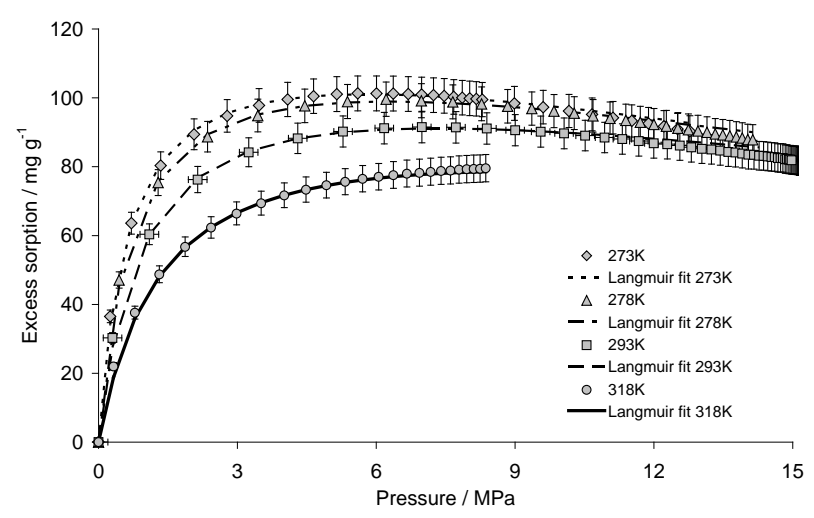

Figure 4. $\mathrm{CH}_{4}$ sorption isotherms measured on $\mathrm{Cu}_{3}(\mathrm{BTC})_{2}$ at $273,278,293$, and $318 \mathrm{~K}$.

the $\mathrm{CH}_{4}$ sorbed phase density at three of the four experimental temperatures (Figure 5, Table 2). For the isotherm measured at $318 \mathrm{~K}$, the pressure is not high enough for a graphical determination. This suggests that the density of the sorbed $\mathrm{CH}_{4}$ phase is independent of the experimental temperature. Maximum absolute sorption capacities, taking into consideration the volume of the sorbed phase, have been determined to be as high as 113, 112, 103 and $90 \mathrm{mg} / \mathrm{g}$ at 273, 278, 293 and $318 \mathrm{~K}$, respectively (Table 2), by applying the following relationship:

$$
n_{a b s}=\left(\frac{1+a p}{a p}\right) \frac{n_{e x}}{1-\left(\frac{\rho_{\text {gas }}}{\rho_{\text {sorbed }}}\right)}
$$

where $n_{e x}$ denotes the excess sorption capacity, $\rho_{g a s}$ the gas phase density, " $a$ " is the Langmuir parameter (1/MPa) and $\rho_{\text {sorbed }}$ the sorbed phase density as determined graphically in Figure 5.

The Langmuir curves shown in Figure 4 were calculated with explicit consideration of the sorbed phase density and therefore, reproduce the decline of the isotherms at high pressures.

In comparison to the study by Senkovska and Kaskel (2007) [13], the $\mathrm{CH}_{4}$ sorption values in this study are lower by a factor of $\sim 1.4$. One explanation might be the reference to the sample mass (or sample density). Senkovska and Kaskel (2007) [13] used a crystallographic density of $0.88 \mathrm{~g} / \mathrm{cm}^{3}$. In this study, sorption values are related to initial weight, while the sample density after activation is $1.77 \pm 0.03 \mathrm{~g} / \mathrm{cm}^{3}$ as determined by helium pycnometry. This lead to a slightly lower sorption amounts for this study in comparison to Senkovska and Kaskel (2007) [13].

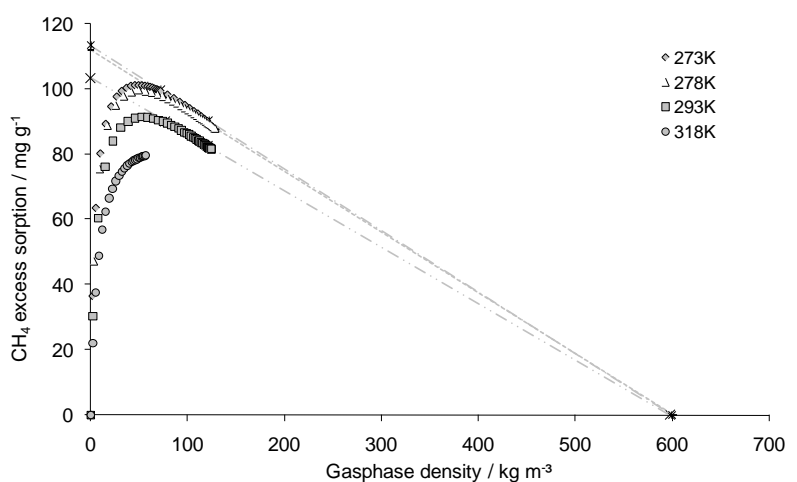

Figure 5. $\mathrm{CH}_{4}$ excess sorption capacities vs. $\mathrm{CH}_{4}$ gas phase density at different temperatures $\left(\mathrm{Cu}_{3}(\mathrm{BTC})_{2}\right.$.

\subsection{Isosteric Heats of Adsorption}

Based on the sorption isotherms measured between 273 and $318 \mathrm{~K}$, isosteric heats of adsorption for $\mathrm{CH}_{4}$ have been calculated using the Clausius-Clapeyron relation (Equation (2)). In this first approximation, the dependence of the adsorption enthalpy on surface coverage was neglected.

$$
\Delta h_{\text {ads }}=\frac{R \cdot T_{1} T_{2}}{T_{2}-T_{1}} \ln \left(\frac{p_{2}}{p_{1}}\right)_{\theta}=\frac{R \cdot T_{1} T_{2}}{T_{2}-T_{1}} \ln \left(\frac{a_{1}}{a_{2}}\right)
$$

where $T_{1}$ and $T_{2}$ are 273 and $318 \mathrm{~K}$, respectively, $p_{1}$ and $p_{2}$ are the $\mathrm{CH}_{4}$ pressures for each isotherm corresponding to an equal fractional coverage $\Theta$ and R denotes the universal gas constant. The parameters $a_{1}$ and $a_{2}$ are constants derived from the linearised Langmuir curve for the two temperatures. For further details, please refer to $\mathrm{Pa}-$ nella et al. (2006) [3].

The isosteric heat of adsorption was calculated based on a Langmuir fit of the experimental data. The decrease in $\mathrm{CH}_{4}$ excess sorption at pressures above $10 \mathrm{MPa}$ is reproduced by introducing a term that accounts for the increase in sorbed phase volume with increasing loading (Equation (1)). For this purpose, the density of the sorbed phase was determined graphically (see Figure 5). The procedure resulted in a very good fit (Figure 4) of the experimentally determined excess sorption values. The Langmuir parameters $a_{1}$ and $a_{2}$ obtained with this method for isotherms at two different temperatures were used in Equation (2) for the calculation of the isosteric heat of adsorption.

Isosteric heats of adsorption for $\mathrm{CH}_{4}$ show an average value of $-11.2 \pm 0.7 \mathrm{~kJ} / \mathrm{mol}$. In this case, a constant density of the sorbate phase was assumed. Using the parameters for the best least square Langmuir fit, an average value of $-12.2 \pm 0.7 \mathrm{~kJ} / \mathrm{mol}$ was obtained. Evaluation of the isosteric heat of adsorption in the low pressure 
range (0 - $4 \mathrm{MPa})$ with the linearised Langmuir fit (providing the same values of absolute adsorption as the graphical evaluation) results in a significantly higher value for the heat of adsorption $(-17.9 \pm 1.3 \mathrm{~kJ} / \mathrm{mol})$.

\subsection{Impact of $\mathrm{CH}_{4}$ Sorption on Pore-Size Distribution}

The pore-size distributions of the initial $\mathrm{Cu}_{3}(\mathrm{BTC})_{2}$ and the samples after successive $\mathrm{CH}_{4}$ and $\mathrm{H}_{2}$ sorption measurements were determined by $\mathrm{N}_{2}$ adsorption at $77 \mathrm{~K}$. In order to describe adsorption on a wider range of microporous materials the Dubinin-Astakhov (DA) equation was used (Dubinin and Astakhov, 1971) [21]. It is a generalized form of the Dubinin-Radushkevich (DR; Dubinin, 1975 [22]) equation and was found to reasonably fit adsorption data for heterogeneous micropores. The results of the evaluations according to the DA method are displayed in Figure 6; the pertaining fitting parameters are listed in Table 3 . The heterogeneity value (n) is higher for homogeneous distributions and is typically between 1 and 3 . For instance, zeolite has an n-value higher than 3 , demonstrating that these materials are very homogeneous. In this study, a value of $n=1$ was determined for $\mathrm{Cu}_{3}(\mathrm{BTC})_{2}$. The characteristic energy $\mathrm{E}$ after Dubinin (1975) was determined to be $20.97 \mathrm{~kJ} / \mathrm{mol}$ for the initial (unspoiled) sample and ranged between 8 and $18 \mathrm{~kJ} / \mathrm{mol}$ after high-pressure $\mathrm{CH}_{4}$ and $\mathrm{H}_{2}$ sorption tests. The interaction constant is given as $k=2.96 \mathrm{~kJ} \cdot \mathrm{nm}^{3} / \mathrm{mol}$ for nitrogen.

From Figure 6 it is evident that $\mathrm{CH}_{4}$ affects the stability of the MOF to a lesser extent than $\mathrm{H}_{2}$. Although a significant decrease in total pore volume is shown after two successive $\mathrm{CH}_{4}$ sorption experiments, accompanied by a shift to larger mean pore radii (4.7 $\AA$ for the original sample; $6.4 \AA$ after six $\mathrm{CH}_{4}$ sorption isotherms; Table 3), a reduction comparable to the $\mathrm{H}_{2}$ treatment is only observed after $6 \mathrm{CH}_{4}$ sorption isotherms. As observed for the $\mathrm{H}_{2}$ treatment, the pore volume in the 5 to $15 \AA$ range is most heavily affected. In this study it is likely that we had chosen a slightly too high activation temperature. However the reason for the different influence of $\mathrm{CH}_{4}$ and $\mathrm{H}_{2}$ on the sample structure is not clear will be investtigated in further detail in a follow-up study.

Results of the evaluation of the micropore structure of the $\mathrm{Cu}_{3}(\mathrm{BTC})_{2}$ before and after high-pressure $\mathrm{CH}_{4}$ sorption isotherms based on the DR method and the nonlinear density functional theory (NLDFT) are summarised in Table 4. These results also support a significant decrease in micropore volume and subsequent reduction in specific surface area of the sample after high-pressure $\mathrm{CH}_{4}$ sorption tests.

Figure 7 compares the high-pressure $\mathrm{CH}_{4}$ excess sorp-

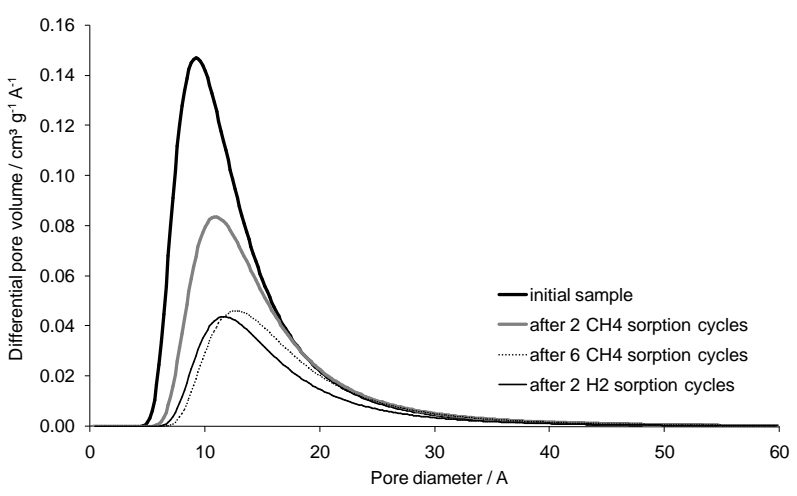

Figure 6. Dubinin Astakov differential pore volume distributions of $\mathrm{Cu}_{3}(\mathrm{BTC})_{2}$ before and after high-pressure $\mathrm{CH}_{4}$ and $\mathrm{H}_{2}$ sorption isotherms. Evaluation based on low-pressure $\mathrm{N}_{2}$-sorption at $77 \mathrm{~K}$.

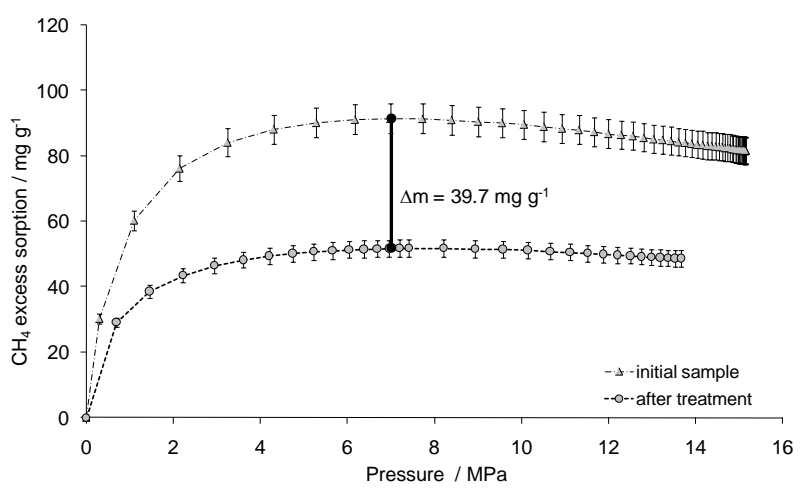

Figure 7. Comparison between initial and $\mathrm{CH}_{4}$ treated $\mathrm{Cu}_{3}(\mathrm{BTC})_{2}$ at $293 \mathrm{~K}$.

tion isotherms measured on the initial Cu-BTC MOF with a decomposed sample of the same material at 293 $\mathrm{K}$. The treated sample shows significantly lower sorption values (decrease of up to $40 \mathrm{mg} / \mathrm{g}$ ) compared to the initial samples, while the shape of the isotherms is similar between the two isotherms.

\section{Conclusions}

At pressures up to $7 \mathrm{MPa}$, Cu-BTC MOF is one of the most promising MOF materials for methane storage with a large uptake capacity and an excess sorption of 9.2 wt $\%$ at $293 \mathrm{~K}$. The repeated thermal activation and highpressure sorption tests with $\mathrm{CH}_{4}$ on HKUST-1 at temperatures between 273 and $318 \mathrm{~K}$ resulted in a reduction of specific micropore volumes and surface area. The processes behind the reduction of the specific micropore volumes and surface area during each $\mathrm{CH}_{4}$ sorption test (Table 4) are ambiguous and further research on this topic is needed.

Recent studies indicate thermal deterioration effects and 
Table 3. Fitting parameters of the DA equation for micropore characterisation of $\mathrm{Cu}_{3}(\mathrm{BTC})_{2}$ before and after $\mathrm{CH}_{4}$ and $\mathrm{H}_{2}$ high-pressure sorption isotherms.

\begin{tabular}{cccc}
\hline $\mathrm{Cu}_{3}(\mathrm{BTC})_{2}$ & $\mathrm{~N}_{2}$ characteristic energy E $[\mathrm{kJ} / \mathrm{mol}]$ & DA heterogeneous value $\mathrm{n}$ & average pore radius $[\AA]$ \\
\hline initial sample & 20.97 & 1 & 4.7 \\
after $2 \mathrm{Ch}_{4}$ isotherms & 18.66 & 1 & 4.9 \\
after $\mathrm{H}_{2}$ isotherms & 11.17 & 1 & 5.8 \\
after $6 \mathrm{CH}_{4}$ isotherms & 8.66 & 1 & 6.4 \\
\hline
\end{tabular}

Table 4. Results of pore structure analysis of $\mathrm{Cu}_{3}(\mathrm{BTC})_{2}$ before and after high-pressure sorption isotherms with $\mathrm{CH}_{4}$.

\begin{tabular}{|c|c|c|c|c|c|c|}
\hline & method & $\begin{array}{c}N_{2} \text { surface area } \\
\left(\mathrm{m}^{2} / \mathrm{g}\right)\end{array}$ & $\begin{array}{c}\mathrm{N}_{2} \text { pore volume } \\
\left(\mathrm{cm}^{3} / \mathrm{g}\right)\end{array}$ & $\begin{array}{c}\mathrm{CO}_{2} \text { surface area } \\
\left(\mathrm{m}^{2} / \mathrm{g}\right)\end{array}$ & $\begin{array}{l}\mathrm{CO}_{2} \text { micropore } \\
\text { volume }\left(\mathrm{cm}^{3} / \mathrm{g}\right)\end{array}$ & $\begin{array}{c}\mathrm{N}_{2} \text { DA pore } \\
\text { diameter }(\AA)\end{array}$ \\
\hline \multirow{2}{*}{ initial sample } & DR & 1731 & 0.62 & 2708 & 0.94 & \multirow{2}{*}{9.2} \\
\hline & NLDFT & 1994 & 0.64 & 2340 & 0.89 & \\
\hline \multirow{2}{*}{ after $2 \mathrm{CH}_{4}$ isotherms } & DR & 1174 & 0.42 & 1226 & 0.43 & \multirow{2}{*}{12.4} \\
\hline & NLDFT & 1186 & 0.55 & 1069 & 0.35 & \\
\hline \multirow{2}{*}{ after $6 \mathrm{CH}_{4}$ isotherms } & DR & 737 & 0.26 & 997 & 0.35 & \multirow{2}{*}{12.8} \\
\hline & NLDFT & 591 & 0.48 & 887 & 0.28 & \\
\hline
\end{tabular}

by interaction with atmospheric air could cause the observed degradation of the sample.

Table 4 shows a stepwise deterioration of the sample after successive $\mathrm{CH}_{4}$ sorption isotherms and the thermal activation process on the identical sample. Further changes caused by exposure to the atmosphere (e.g. oxidation of the sample) can be neglected, since samples did not come in contact with atmospheric air from the beginning of the thermal activation process (only $\mathrm{H}_{2}, \mathrm{CH}_{4}$ and $\mathrm{He}$ ). However, it is unclear as of yet why micropores volumes decrease drastically and larger pores remain preserved.

Finally, this study has shown that the $\mathrm{CH}_{4}$ sorbed phase density is, within reasonable errors, independent of temperature.

\section{Acknowledgments}

I am greatly indebted to Stefan Kaskel for providing 2007 the samples and Joachim Borchardt for technical support. The fruitful discussion and remarks of Bernd Krooß, Andreas Busch, Susan Giffin and Dirk Prinz are greatly appreciated.

\section{REFERENCES}

[1] M. Eddaoudi, J. Kim, N. Rosi, D. Vodak, J. Wachter, M. O’Keeffe and O. M. Yaghi, "Systematic Design of Pore Size and Functionality in Isoreticular MOFs and Their Application in Methane Storage,” Science Magazine, Vol. 295, No. 5554, 2002, pp. 469-472. doi:10.1126/science.1067208

[2] N. Amaroli and V. Balzani, "The Future of Energy Supply: Challenges and Opportunities," General and
Introductory Chemistry, Vol. 46, No. 1-2, 2007, pp. 52-66. doi:10.1002/anie.200602373

[3] B. Panella, M. Hirscher, H. Pütter and U. Müller, "Hydrogen Adsorption in Metal-Organic Frameworks: Cu-MOFs and Zn-MOFs Compared," Advanced Functional Materials, Vol. 16, No. 4, 2006, pp. 520-524. doi:10.1002/adfm.200500561

[4] H. Li, M. Eddaoudi, M. O’Keeffe and O. M. Yaghi, "Design and Synthesis of an Exceptionally Stable and Highly Porous Metal-Organic Framework,” Nature, Vol. 402, pp. 276-279. doi:10.1038/46248

[5] S. Y. Chui, et al., "A Chemically Functionalizable Nanoporous Material $\left[\mathrm{Cu}_{3}(\mathrm{TMA})_{2}\left(\mathrm{H}_{2} \mathrm{O}\right)_{3}\right]_{\mathrm{n}}$," Science Magazine, Vol. 283, No. 5405, 1999,pp. 1148-1150. doi: 10.1126/science.283.5405.1148

[6] K. Schlichte, T. Kratzke and S. Kaskel, "Improved synthesis, Thermal Stability and Catalytic Properties of The Metal-Organic Framework Compound $\mathrm{Cu}_{3}(\mathrm{BTC})_{2}$," Microporous and Mesoporous Materials, Vol. 73, No. 1-2, 2004, pp. 81-88. doi:10.1016/j.micromeso.2003.12.027

[7] B. Panella and M. Hirscher. "Hydrogen Physisorption in Metal-Organic Porous Systems,” Advanced Material, Vol. 17, No. 5, 2005, pp. 538-541. doi:10.1002/adma.200400946

[8] G. Férey, M. Latroche, C. Serre, F. Millange, T. Loiseau and A. Percheron-Guégan, "Hydrogen Adsorption in the Nanoporous Metal-Benzenedicarboxylate $\mathrm{M}(\mathrm{OH})\left(\mathrm{O}_{2} \mathrm{C}-\right.$ $\left.\mathrm{C}_{6} \mathrm{H}_{4}-\mathrm{CO}_{2}\right)\left(\mathrm{M}=\mathrm{Al}_{3}+, \mathrm{Cr}_{3}+\right)$, MIL-53," Chemical Communications, No. 24, 2003, pp. 2976-2977. doi: 10.1039/B308903G

[9] M. G. Nijkamp, J. E. M. J. Raaymakers, A. J. van Dillen and K. P. de Jong "Hydrogen Storage Using Physisorption - Materials Demands," Applied Physics A Materials Science \& Processing, Vol. 72, No. 5, 2001, pp. 
619-623.

[10] J. Beneyto, F. Suárez-García, D. Lozano-Castelló, D. Cazorla-Amorós and A. Linares-Solano, "Hydrogen Storage on Chemically Activated Carbons and Carbon Nanomaterials at High Pressures," Carbon, Vol. 45, No. 2, 2007, pp. 293-303. doi:10.1016/j.carbon.2006.09.022

[11] Q. M. Wang, D. Shen, M. Bulow, M. L. Lau, S. Deng, F. R. Fitch and N. O. Lemcoff, J. Semanscin, "Metallo-Organic Molecular Sieve for Gas Separation and Purification," Microporous and Mesoporous Materials, Vol. 55, No. 2, 2002, pp. 217-230. doi:10.1016/S1387-1811(02)00405-5

[12] X. Lin, A. J. Blake, C. Wilson, X. Z. Sun, N. R. Champness, M. W. George, P. Hubberstey, R. Mokaya and M. Schroder, "A Porous Framework Polymer Based on a Zinc(II) 4,4'-Bipyridine-2,6,2‘, 6‘-Tetracarboxylate: Synthesis, Structure, and 'Zeolite-Like' Behaviors," Journal of American Chemical Society, Vol. 128, No. 33, 2006, pp. 10745-10753. doi:10.1021/ja060946u

[13] J. Senkovska and S. Kaskel, "High Pressure Methane Adsorption in the Metal-Organic Frameworks $\mathrm{Cu}_{3}(\mathrm{BTC})_{2}$, $\mathrm{Zn}_{2}$ (bdc) $)_{2}$ dabco, and $\mathrm{Cr}_{3} \mathrm{~F}\left(\mathrm{H}_{2} \mathrm{O}\right)_{2} \mathrm{O}(\mathrm{bdc})_{3}$," Microporous and Mesoporous Materials, Vol. 112, No. 1-3, 2008, pp. 108-115. doi:10.1016/j.micromeso.2007.09.016

[14] U. Setzmann and W. Wagner, "A New Equation of State and Tables of Thermodynamic Properties for Methane Covering the Range From the Melting Line to $625 \mathrm{~K}$ at pressures up to $1000 \mathrm{MPa}$," Journal of Physical and Chemical Reference Data , Vol. 20, No. 6, 1991, pp. 1061-1155. doi:10.1063/1.555898

[15] R. D. McCarty and V. D Arp, "A New Wide Range Equation of State for Helium,” Advances in Cryogenic Engineering, Vol. 35, 1990, pp. 1465-1475.

[16] Y. Gensterblum, P. van Hemert, P. Billemont, A. Busch, D. Charriere, D. Li, B. M. Krooss, G. de Weireld, D. Prinz and K.-H. A. A. Wolf, "European Inter-Laboratory Comparison of High Pressure $\mathrm{CO}_{2}$ Sorption Isotherms. I: Activated Carbon,” Carbon, Vol. 47, No. 13, 2009, pp. 2958-2969. doi:10.1016/j.carbon.2009.06.046

[17] A. L. Goodman, A. Busch, G. Duffy, J. E. Fitzgerald, et al., "An Inter-laboratory Comparison of $\mathrm{CO}_{2}$ Isotherms Measured on Argonne Premium Coal Samples,” Energy and Fuels, Vol. 18, No. 4, 2004, pp. 1175-1182. doi:10.1021/ef034104h

[18] Y. Gensterblum, P. Van Hemert, P. Billemont, et al.,
"European inter-laboratory comparison of high pressure $\mathrm{CO}_{2}$ sorption isotherms II: Natural coals,” International Journal of Coal Geology, Vol. 84, No. 2, 2010, pp. 115-124. doi:10.1016/j.carbon.2009.06.046

[19] A. Busch, Y. Gensterblum, B. M. Krooss and R. Littke, "Methane and Carbon Dioxide Adsorption-Diffusion Experiments on Coal: An upscaling and Modelling," International Journal of Coal Geology, Vol. 60, No. 2-4, 2004, pp. 151-168. doi:10.1016/j.coal.2004.05.002

[20] S. Brunauer, P. H. Emmett and E. Teller, “Adsorption of Gases in Multimolecular Layers," Journal of American Chemical Society, Vol. 60, No. 2, 1938, pp. 309-319. doi:10.1021/ja01269a023

[21] M. M. Dubinin, "Physical Adsorption of Gases and Vapors in Micropores,” Academic Press, New York, 1975, p. $1-70$.

[22] M. M. Dubinin and V. A. Astakhov, "Description of Adsorption Equilibria of Vapors on Zeolites over Wide Ranges of Temperature And Pressure," Advances in Chemistry, Vol. 102, No. 69, 1971, pp. 65-69. doi:10.1021/ba-1971-0102.ch044

[23] M. Thommes, B. Smarsly, M. Groenevolt, P. I. Ravikovitch and A.V. Neimark, "Adsorption Hysteresis of Nitrogen and Argon in Pore Networks and Characterization of Novel Micro- and Mesoporous Silicas," Langmuir, Vol. 22, Vol. 2, 2006, pp. 756-764. doi:10.1021/la051686h

[24] M. Kramer, U. Schwarzer, S. Kaskel, "Synthesis and properties of the metal-organic framework $\mathrm{Mo}_{3}(\mathrm{BTC})_{2}$ (TUDMOF-1)” Journal of Material Chemistry, Vol. 16, 2006, pp. 2245-2248. doi:10.1039/b601811d

[25] P. Krawiec, M. Kramer, M. Sabo, R. Kunschke, H. Fröde and S. Kaskel, "Improved Hydrogen Storage in the Metal-Organic Framework $\mathrm{Cu}_{3}(\mathrm{BTC})_{2}$ ” Advanced Engineering Material, Vol. 8, No. 4, 2006, pp. 293-296. doi:10.1002/adem.200500223

[26] A. R. Millward and O. M. Yaghi, "Metal-Organic Frameworks with Exceptionally High Capacity for Storage of Carbon Dioxide at Room Temperature," Journal of American Chemical Society, Vol. 127, No. 51, 2005, pp 17998-17999. doi:10.1021/ja0570032

[27] R. Humayun, D. L. Tomasko, "High-Resolution AdsorpTion Isotherms of Supercritical Carbon Dioxide on Activated Carbon,” AICHE Journal, Vol. 46, No. 10, 2000,pp. 2065-2075. doi:10.1002/aic.690461017 